\title{
Up-To-Date Insight on Industrial Enzymes Applications and Global Market
}

Boutros Sarrouh $^{1 *}$, Tulio Marcos Santos ${ }^{2}$, Anderson Miyoshi ${ }^{1}$, Rodrigo Dias $^{1}$ and Vasco Azevedo

${ }^{1}$ Institute of Biological Sciences, Federal University of Minas Gerais (UFMG-ICB), Belo Horizonte - MG, CEP 31270-901, Brazil

${ }^{2}$ Uniclon Biotecnologia Ltda. Belo Horizonte -MG, CEP 31035-536, Brazil

\begin{abstract}
Industrial and household catalysis becomes more and more dependent on enzymes. This is not surprising since enzymes are able to catalyze all kinds of chemical reactions. Enzymes with the desired activity under industrial conditions can be obtained by optimizing process conditions and by protein engineering. The use of enzymes frequently results in many benefits that cannot be obtained with traditional chemical treatment. These often include higher product quality and lower manufacturing cost, less waste and reduced energy consumption. Key factors driving the market growth include new enzyme technologies endeavoring to enhance cost efficiencies and productivity, and growing interest among consumers in substituting petrochemical products with other organic compounds such as enzymes. Other factor propelling market growth includes surging demand from textile manufacturers, animal feed producers, detergent manufacturers, pharmaceutical companies, bioethanol producers and cosmetics vendors. The present paper aims to provide a review on industrial enzymes, highlighting on recent scientific advances, current applications in diverse industrial sectors and global market.
\end{abstract}

Keywords: Industrial enzymes; Protein engineering; Enzyme applications; Global market

\section{Introduction}

Industrial and household catalysis becomes more and more dependent on enzymes. This is not surprising since enzymes are able to catalyze all kinds of chemical reactions. They can perform conversions in minutes or even seconds, which would take hundreds of years without their interference $[1,2]$. Furthermore, they catalyze reactions, which are difficult to perform by chemical methods, like the enantio-or regioselective hydrolysis or addition of chiral groups. Since all of these features are generally displayed at room temperature under mostly aqueous conditions the research towards the use of biocatalysts is mainly driven by the necessity of using sustainable technologies for the production of chemicals (green routes) and complex active ingredients in a pharmaceutical and agrobiological context [2,3].

This "white biotechnology" remains a challenge since new biocatalytic processes have to compete economically with the well-established chemical processes that have been optimized for years [2]. Although many complicated chemical reactions can be efficiently performed by biocatalysts, industrial conditions are usually different from those in nature with respect to substrate concentrations, sheering forces, temperature and organic solvents. Therefore, most enzymes found in soil and water may display the desired activity, but are generally not suited for industrial use $[2,4]$. Furthermore, for numerous industrial chemical processes an adequate enzyme cannot be readily found in nature, implying that there is a need for novel biocatalysts. Enzymes with the desired activity under industrial conditions can be obtained by optimizing process conditions and by protein engineering using directed evolution $[1,2,5]$.

Directed evolution is a term used to describe the entire range of molecular biology techniques that allow natural evolutionary processes to be mimicked in the laboratory. For enzymes, this generally involves the random mutagenesis of one or more starting genes, followed by a screening or selection step to isolate or enrich for enzyme variants with improvements in one or more desirable properties [1].

Marrs et al. [4] considered that industrial biocatalysis is widely viewed as the 'third wave' of biotechnology following the pharmaceutical and agricultural waves. Biological catalysts are attractive for indus- trial purposes, not only because they are highly selective and efficient in substrate-to-product bioconversion, but also because they tend to catalyze the production of relatively pure products, thus minimizing waste generation. These catalysts are able to carry out regiospecific, chemospecific and estereospecific reactions that are challenging for conventional chemistries. These reactions occur under mild conditions with comparatively nontoxic reagents. Not every biological catalyst however, is useful as industrial enzyme.

Significant technological sophistication is usually required to produce industrial scale quantities of biological catalyst at reasonable cost. These three considerations, which are sometimes summarized as volumetric productivity, stability and availability, are the hurdles that must be overcome before a biological catalyst can be considered an industrial enzyme [4].

\section{Industrial Enzymes: Classification and Selection Crite-} ria

The role of enzymes in many processes has been known for a long time. Their existence was associated with the history of ancient Greece where they were using enzymes from microorganisms in baking, brewing, alcohol production, cheese making etc. With better knowledge and purification of enzymes the number of applications has increased manyfold, and with the availability of thermostable enzymes a number of new possibilities for industrial processes have emerged [6].

The International Union of Biochemistry and Molecular Biology (IUBMB) classified enzymes into six major groups (classes), according to the type of reaction they catalyze [7]

*Corresponding author: Boutros Sarrouh, Institute of Biological Sciences, Federal University of Minas Gerais (UFMG-ICB), Belo Horizonte - MG, CEP 31270-901, Brazil, Tel +55 31 34092982; Email:- bsarrouh@yahoo.es

Received October 24, 2011; Accepted January 13, 2012; Published January 16 2012

Citation: Sarrouh B, Santos TM, Miyoshi A, Dias R, Azevedo V (2012) Up-ToDate Insight on Industrial Enzymes Applications and Global Market. J Bioprocess Biotechniq S4:002 doi:10.4172/2155-9821.S4-002

Copyright: @ 2012 Sarrouh B, et al. This is an open-access article distributed unde the terms of the Creative Commons Attribution License, which permits unrestricted use, distribution, and reproduction in any medium, provided the original author and source are credited. 
1. Oxidoreductases: All enzymes catalyzing oxidoreduction reactions belong to this class. The substrate that is oxidized is regarded as hydrogen donor.

2. Transferases: Transferases are enzymes which transfer a group, e.g. a methyl group or a glycosyl group, from one compound (generally regarded as donor) to another compound (generally regarded as acceptor).

3. Hydrolases: These enzymes catalyse the hydrolytic cleavage of $\mathrm{C}-\mathrm{O}, \mathrm{C}-\mathrm{N}, \mathrm{C}-\mathrm{C}$ and some other bonds, including phosphoric anhydride bonds.

4. Lyases: Lyases are enzymes cleaving C-C, C-O, C-N, and other bonds by elimination, leaving double bonds or rings, or conversely adding groups to double bonds.

5. Isomerases: These enzymes catalyse geometric or structural changes within one molecule.

6. Ligases: Enzymes that catalyze the joining together of two molecules coupled with the hydrolysis of a diphosphate bond in ATP or a similar triphosphate.

Each enzyme described receives a classification number, known as "EC" (Enzyme Commission of the IUBMB), which is composed of four digits [7]:

1. Class

2. Subclass within the class

3. Specific chemical groups that participate in the reaction.

4. The enzyme itself

Examples of the classification numbers of each enzyme can be consulted in Figure $1[8]$.

Figure 2 illustrates the ideal biocatalyst concept, where each enzyme candidate from the metagenome is ranked, from low (rating of 1) to high (rating of 6) using a specific set of criteria, to produce a multi- parameter fingerprint (shown in yellow) [9]. Criteria include in vitro enzyme activity, efficiency, specificity and stability. This decision matrix reveals the strengths and weaknesses of every candidate enzyme, so that the most promising candidate enzymes from diverse enzyme libraries can be selected for further process development by re-screening, protein engineering or directed evolution methods [9].

Because enzymes are so unique in function and activity, they are easily deactivated when no longer needed. It is this ability to perform highly distinct, biocatalytic, complex chemical reactions without harsh chemistries or excessive energy that makes enzymes so attractive for industrial use.

\section{Genetically Engineered Enzymes}

The significant progress in genetics and in process technology enables the enzyme industry to offer products with improved properties and often at reduced costs. Falch [10] claimed that genetic engineering enables us to select host organisms and cultivation conditions that are safe to the manufacturing personnel, to the user of the product, and to the environment at large. Often an enzyme with interesting properties is found in an organism which is insufficiently characterized or is related to a toxin-producing or to an opportunistic pathogenic organism. Such uncertainty can now be avoided by transfer of the enzyme gene to a safe host using protein engineering tools (Table 1). Genetic engineering opens new avenues to enzymes with improved stability, activity or specificity and productivity [10]. Due to this fact, enzymes naturally occurring in other organisms may now be produced in largescale fermentation processes. Enzymes of animal or plant origin may be produced independently of the supply of animal and plant tissue. Chymosin, the active protease in calf rennin, is already being produced by enzymes found in minute concentrations in exotic microorganisms often difficult to grow may be produced by selecting host microorganisms which are easy to cultivate on cheap raw materials and producing a broth from which the enzyme is easy to purify [10].

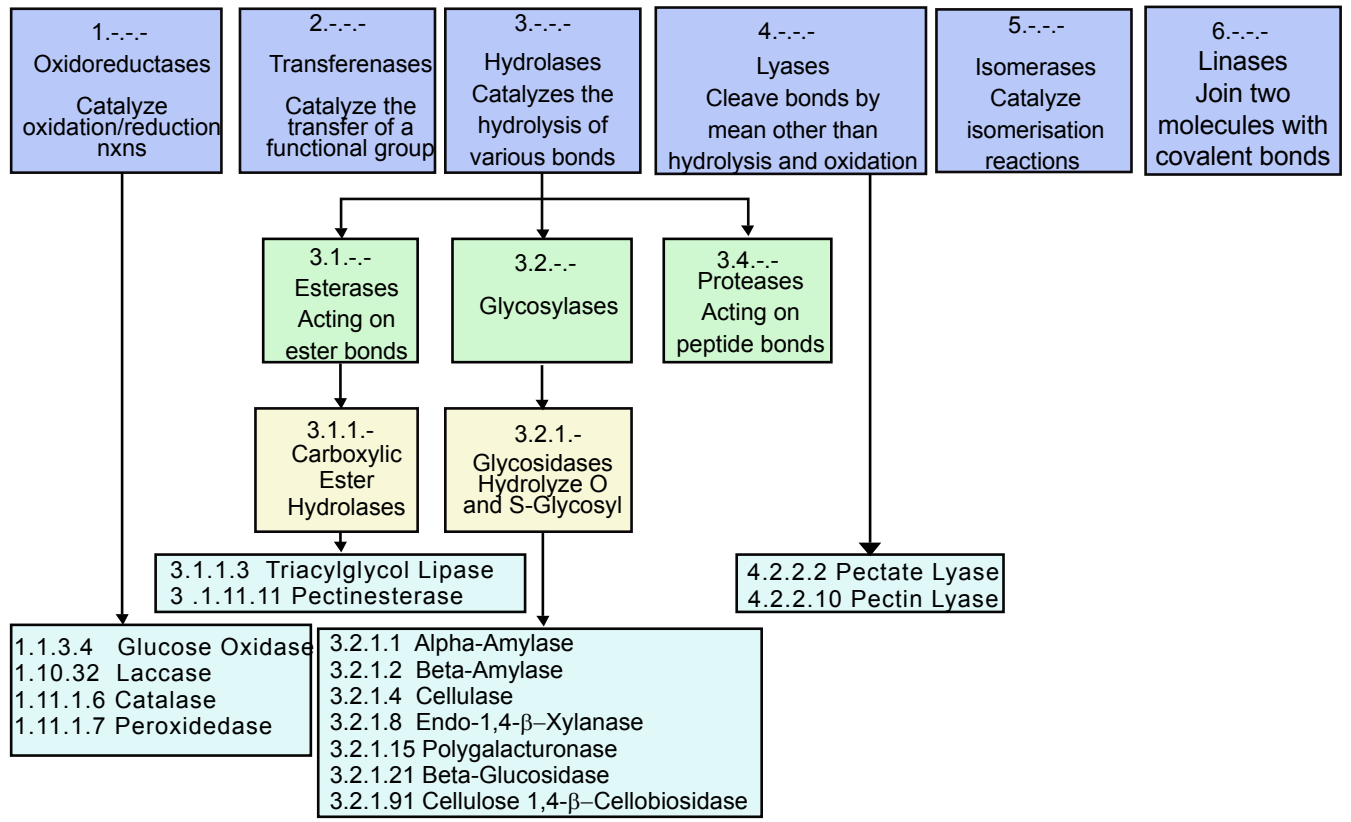

Figure 1: General Classification of enzymes based on their catalytic functions. 


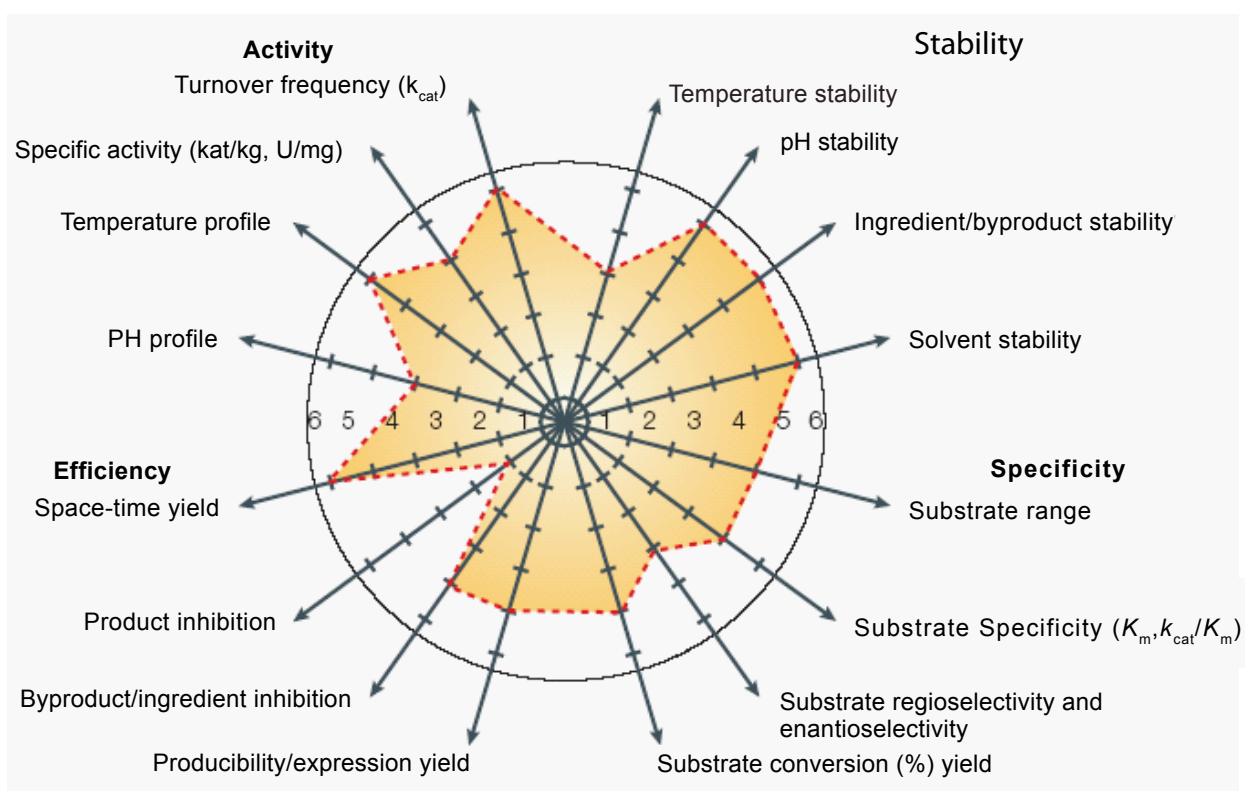

Figure 2: Construction of a multi-parameter decision matrix for an efficient candidate enzyme selection. Catalytic reaction rate ( $k c a t)$, catalytic constant (Km), Michaelis constant $(U)$.

According to Leisola et al. [11] several enzymes have already been engineered to function better in industrial processes. These include proteinases, lipases, cellulases, $\alpha$-amylases and glucoamylases.

Otten and Quax [2] in their paper outlined that, xylanases have received great attention in the development of environment-friendly technologies in the paper and pulp industry, where large-scale production of xylanases is facilitated with the progress of genetic engineering. The same authors emphasized that, recent breakthroughs in genomics have helped to overcome the problems such as limited enzyme availability, substrate scope, and operational stability. Genes encoding xylanases have been cloned in homologous and heterologous hosts with the objectives of overproducing the enzyme and altering its properties to suit commercial.

Aravindan et al. [12] highlighted that protein engineering of lipases was studied based on the sequence information since the mid of 1980s. Many lipases have been engineered for thermostability, protease stability and for oxidative stability. A. niger was developed as an important transformation host to overexpress food enzymes since it has been considered GRAS (Generally Recognized As Safe) by the US Food and Drug Administration [12].

Another example is the successful application of laccases in food processing. Several production strategies can be adopted along with media and process optimization to achieve production of high amounts at reduced costs. Concomitantly, overexpression of laccase in suitable host organisms would provide means to achieve high titers. Use of inducers could also enhance production capabilities [13].

Table 2 shows some examples of enzymes produced by genetically modified microorganisms and their application in food industry.

\section{Industrial Enzymes: Production and Application}

Industrial enzymes are produced by fermentation using microorganisms such as bacteria or fungi under carefully controlled conditions. Currently, researchers are locating extremophile organisms from around the world that produce enzymes of a promising industrial nature $[6,8,14]$. These searches range from the rain forests to remote arid regions to the bottom of the ocean. In some cases, these bacteria or fungi can be modified to produce additional interesting enzyme varieties.

In practice, the great majority of microbial enzymes come from a very limited number of genera, of which Aspergillus species, Trichoderma species, Bacillus species and Kluyveromyces species predominate $[8,15]$. Most of the strains used, have either been employed by the food industry for many years or have been derived from such strains by mutation and selection [15].

In choosing the production strain several aspects have to be considered. Ideally the enzyme is secreted from the cell. This makes the recovery and purification process much simpler compared to production of intracellular enzymes, which must be purified from thousands of different cell proteins and other components. Secondly, the production host should have a GRAS-status (Generally Regarded As Safe). This is especially important when the enzyme produced by the organism is used in food processes. Thirdly, the organism should be able to produce high amount of the desired enzyme in a reasonable time frame. Most of the industrially used microorganisms have been genetically modified to overproduce the desired activity and not to produce undesired side activities [8].

\begin{tabular}{|l|l|}
\hline Target & Method \\
\hline Protein structure & Crystallization \\
\hline Xodelling and simulation & NMR crystallography \\
\hline Gene & Computational methods, Bioinformatics \\
\hline & $\begin{array}{l}\text { Plasmids } \\
\text { Expression systems }\end{array}$ \\
\hline $\begin{array}{l}\text { Targeted mutagenesis } \\
\text { PCR }\end{array}$ \\
\hline DNA shuffling \\
\hline Random mutagenesis \\
\hline
\end{tabular}

Table 1: Tools in protein engineering [11]. 
Citation: Sarrouh B, Santos TM, Miyoshi A, Dias R, Azevedo V (2012) Up-To-Date Insight on Industrial Enzymes Applications and Global Market. J Bioprocess Biotechniq S4:002 doi:10.4172/2155-9821.S4-002

Page 4 of 10

\begin{tabular}{|c|c|c|c|c|}
\hline Principle Enzymatic Activity & Host Organism (production organism) & Donor Organism & Application Examples & Price* $\$ / \mathrm{Kg}$ \\
\hline$\alpha$-Acetolactate decarboxylase & Bacillus amyloliquefaciens or subtilis & Bacillus sp. & Beverages & $50-60$ \\
\hline$\alpha$-Amylase (Thermal) & $\begin{array}{l}\text { Bacillus amyloliquefaciens } \\
\text { Bacillus licheniformis }\end{array}$ & $\begin{array}{l}\text { Bacillus sp. } \\
\text { Bacillus sp. }\end{array}$ & $\begin{array}{l}\text { Cereal, Beverages } \\
\text { Sugar, Bakery }\end{array}$ & $1500-10.000$ \\
\hline Catalase & Aspergillus niger & Aspergillus sp. & Milk, Egg & $1000-10.000$ \\
\hline Chymosin & $\begin{array}{l}\text { Aspergillus niger var. awamori/ } \\
\text { Kluyveromyces lactis }\end{array}$ & Calf stomach & Cheese & $460-500$ \\
\hline Cyclodextrin glucano trans-ferase & Bacillus licheniformis & Thermoanaero-bacter sp. & Cereal & $N / A^{*}$ \\
\hline ß-Glucanase & $\begin{array}{l}\text { Bacillus amyloliquefaciens/ subtilis/ } \\
\text { Trichoderma reesei or longibrachiatum }\end{array}$ & $\begin{array}{l}\text { Bacillus sp. } \\
\text { Trichoderma sp. }\end{array}$ & $\begin{array}{l}\text { Cereal, Beverages } \\
\text { Cereal, Dietary food }\end{array}$ & N/A \\
\hline $\begin{array}{l}\text { Glucose } \\
\text { isomerase }\end{array}$ & $\begin{array}{l}\text { Streptomyces lividans/ } \\
\text { Streptomyces rubiginosus }\end{array}$ & $\begin{array}{l}\text { Actinoplanes sp. } \\
\text { Streptomyces sp. }\end{array}$ & Cereal & N/A \\
\hline $\begin{array}{l}\text { Glucose } \\
\text { oxidase }\end{array}$ & Aspergillus niger & Aspergillus sp. & Egg, Beverages, Bakery, Salads & $182-186$ \\
\hline Hemicellulase & Bacillus amyloliquefaciens or subtilis & Bacillus sp. & Bakery & N/A \\
\hline Lipase yt & Aspergillus oryzae & $\begin{array}{l}\text { Candida sp./ } \\
\text { Rhizomucor sp./ } \\
\text { Thermomyces sp. }\end{array}$ & $\begin{array}{l}\text { Fats } \\
\text { Fats, Bakery }\end{array}$ & $202-206$ \\
\hline Maltogenic amylase & Bacillus amyloliquefaciens or subtilis & Bacillus sp. & Cereal, Beverages, Bakery & $50-1500$ \\
\hline Protease (Neutral) & $\begin{array}{l}\text { Aspergillus oryzae/ } \\
\text { Bacillus amyloliquefaciens or subtilis. } \\
\text { Bacillus licheniformis }\end{array}$ & $\begin{array}{l}\text { Rhizomucor sp. } \\
\text { Bacillus sp. } \\
\text { Bacillus sp. }\end{array}$ & $\begin{array}{l}\text { Cheese, Meat, Fish, Cereal } \\
\text { Beverages, Bakery Salads } \\
\text { Meat, Fish }\end{array}$ & $3-30$ \\
\hline Pullulanase & $\begin{array}{l}\text { Bacillus licheniformis/ } \\
\text { Klebsiella planticola }\end{array}$ & $\begin{array}{l}\text { Bacillus sp. } \\
\text { Klebsiella sp. }\end{array}$ & $\begin{array}{l}\text { Cereal } \\
\text { Cereal, Beverages, Bakery }\end{array}$ & $15-30$ \\
\hline Xylanase & $\begin{array}{l}\text { Aspergillus oryzae } \\
\text { Aspergillus niger var. awamori/ } \\
\text { Bacillus amyloliquefaciens or subtilis/ } \\
\text { Bacillus licheniformis/ } \\
\text { Trichoderma reesei or longibrachiatum }\end{array}$ & $\begin{array}{l}\text { Aspergillus sp. Thermomyces sp./ } \\
\text { Bacillus sp./ } \\
\text { Bacillus sp./ } \\
\text { Trichoderma sp. }\end{array}$ & $\begin{array}{l}\text { Cereal } \\
\text { Cereal, Bakery } \\
\text { Bakery, Cereal, Beverage } \\
\text { Cereal } \\
\text { Cereal, Beverages }\end{array}$ & $10-80$ \\
\hline
\end{tabular}

*Range of prices is based on values given by the manufacturer/seller in the site: http://www.alibaba.com/ N/A: not available.

Table 2: List of commercial enzymes from genetically modified microorganisms used in food industry, adapted from [14]. Table 2: List of commercial enzymes from genetically modified microorganisms used in food industry, adapted from [14].

Leisola et al. [11] divided the enzyme production process into following phases:

1. Selection of an enzyme.

2. Selection of a production strain.

3. Construction of an overproducing strain by genetic engineering.

4. Optimization of culture medium and production conditions.

5. Optimization of recovery process.

6. Formulation of a stable enzyme product.

According to the same authors, criteria used in the selection of an industrial enzyme include specificity, reaction rate, $\mathrm{pH}$ and temperature and stability, effect of inhibitors and affinity to substrates [11].

Enzyme production techniques can be used to tailor the chemical reactions of the enzymes for specific types of industrial activity and operating conditions such as temperature, $\mathrm{pH}$, and reaction kinetics [8].

Industrial production of enzymes requires a clear understanding of the associated scientific and technological issues. These issues range from identification of the biological sources for enzyme production to their genetic manipulation for overproduction, strategies for cell cultivation, isolation, purification and stabilization.

A good example of a layout for large scale enzyme production of frutosyltransferase (FTase) from Aureobasidium pullulans was presented in the work of Vaňková et al. [16], as shown in Figure 3. Since FTase of A. pullulans occurs in the periplasmic space of cells and so the part of the enzyme is easily released to the cultivation medium. Therefore, the recovery of the enzyme was considered from both the harvested cells and cultivation medium.

On the basis of application, industrial enzymes could be divided into four major categories, i.e. detergent enzymes, technical enzymes, food enzymes and feed enzymes. The technical enzymes segment could further be divided into textile enzymes, leather enzymes, pulp and paper enzymes, fine chemicals enzymes, fuel ethanol enzymes and others $[17,18]$.

Enzymes can often replace chemicals or processes that present safety or environmental issues [19]. For example, enzymes can:

- Replace acids in the starch processing industry and alkalis or oxidizing agents in fabric desizing;

- Reduce the use of sulfide in tanneries;

- Replace pumice stones for "stonewashing" jeans;

- Allow for more complete digestion of animal feed leading to less animal waste;

- Remove stains from fabrics.

- Clothes can be washed at lower temperatures, thus saving energy

A report presented by the Enzyme Technical Association [20], outlined that enzymes can be used instead of chlorine bleach for removing 


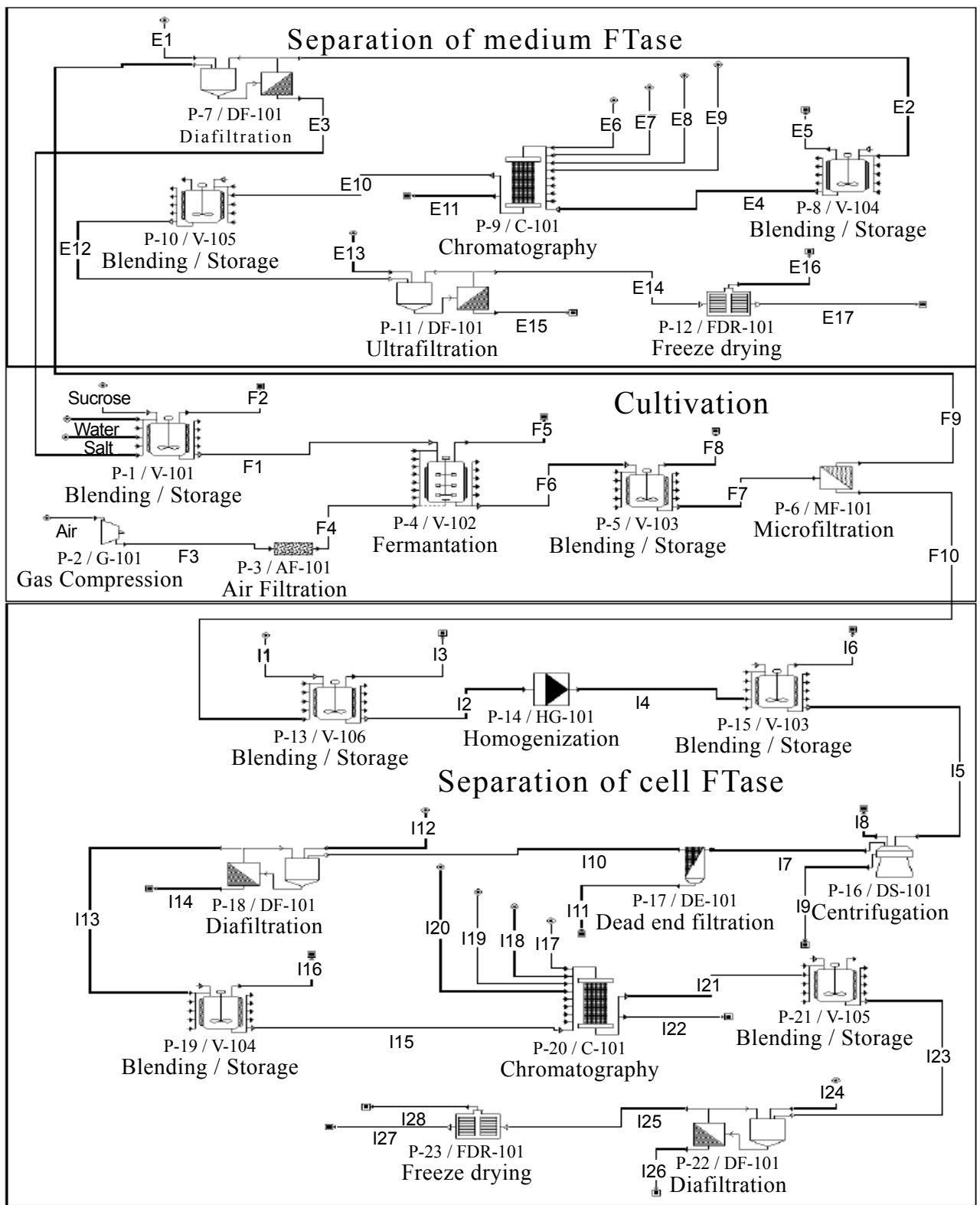

Figure 3: Process flowsheet of industrial production of frutosyltransferase (FTase). Streams are denoted by alphanumeric codes where F denotes the cultivation part, $\mathrm{E}$ the part of the cell FTase separation, and I the part of the medium FTase separation.

stains on cloth. The use of enzymes also allows the level of surfactants to be reduced and permits the cleaning of clothes in the absence of phosphates. Enzymes also contribute to safer working conditions through elimination of chemical treatments during production processes. For example, in starch, paper and textile processing, less hazardous chemicals are required when enzymes are used.

The major enzymes used in industrial enzymes market are amylase, lipase, protease, ligase, phytase, cellulase, xylanase, between others [2124]. Food enzymes constitute the major market share of the all four categories of industrial enzymes [19].

In reference to data provided by a published report on global industrial enzyme market [19], the growth registered by technical enzymes segment was highest in past 4-5 years due to dramatic growth of the fuel ethanol enzymes segment. The global fuel ethanol enzymes industry constituted about $11 \%$ of the global industrial enzymes market in 2009 and the market has increased at an annual growth rate of $15 \%-20 \%$ in the past few years.

The development of commercial enzymes is a specialized business which is usually undertaken by a handful of companies which have high skills in [25]:

- Screening for new and improved enzymes.

- Fermentation for enzyme production.

- Large scale enzyme purifications.

- Formulation of enzymes for sale.

The enzyme industry is in an excellent position to contribute to a 
cleaner environment. First of all, enzyme technology offers industries and consumers an opportunity to replace processes using aggressive chemicals with mild, non-toxic enzyme processes. Secondly, the biotechnological processes used to produce enzymes have a minimal impact on the environment.

\section{Enzyme Immobilization}

The use of enzymes in industrial applications has been limited by several factors, mainly the high cost of the enzymes, their instability, and availability in small amounts. Also the enzymes are soluble in aqueous media and it is difficult and expensive to recover them from reactor effluents at the end of the catalytic process. This restricts the use of soluble enzymes to batch operations, followed by disposal of the spent enzyme-containing solvent [26].

Over the last few decades, intense research in the area of enzyme technology has provided many approaches that facilitate their practical applications. Among them, the newer technological developments in the field of immobilized biocatalysts can offer the possibility of a wider and more economical exploitation of biocatalysts in industry, waste treatment, medicine, and in the development of bioprocess monitoring devices like the biosensor [26-28].

D'Souza [26] stated that, immobilization means associating the biocatalysts with an insoluble matrix so that it can be retained in adequate reactor geometry for its economic reuse under stabilized conditions. Immobilization helps in the development of continuous processes allowing more economic organization of the operations, automation, decrease of labour, and investment/capacity ratio. Immobilized biocatalysts offer several other advantages; notable among them is the availability of the product in greater purity. The same author highlighted that the purity of the product is very crucial in food processing and pharmaceutical industry since contamination could cause serious toxicological, sensory, or immunological problems. The other major advantages include greater control over enzymatic reaction as well as high volumetric productivity with lower residence time, which are of great significance in the food industry, especially in the treatment of perishable commodities as well as in other applications involving labile substrates, intermediates or products $[26,29]$.

A large number of techniques and supports are now available for the immobilization of enzymes or cells on a variety of natural and synthetic supports. The choice of the support as well as the technique depends on the nature of the enzyme, nature of the substrate and its ultimate application. Commercial success has been achieved when support materials have been chosen for their flow properties, low cost, nontoxicity, maximum biocatalysts loading while retaining desirable flow characteristics, operational durability, ease of availability, and ease of immobilization [30].

Biocatalysts can be immobilized either using the isolated enzymes or the whole cells [31]. Immobilization of whole cells, due to operational facility, has been shown to be an easier alternative to immobilization of isolated enzyme. On the other hand, immobilized cells showed lower catalytic activity compared with immobilized enzymes.

Enzymes are good catalysts in terms of high catalytic and specific activity with ability to function under mild conditions. However, they are not always ideal catalysts for practical applications because they are generally unstable and they inactivate rapidly through several mechanisms [32].

Techniques for immobilization have been broadly classified into four categories, namely entrapment, covalent binding, cross-linking and adsorption and the combination of one or more of these physical techniques together with chemical conjugation techniques [27-29,3239]. It must be emphasized that in terms of economy of a process, both the activity and the operational stability of the biocatalysts are important. They determine its productivity, which is the activity integrated over the operational time [26].

Immobilization often stabilizes the structure of enzymes, thereby, allowing their applications even under harsh environmental conditions of $\mathrm{pH}$, temperature and organic solvents, and thus enable their uses at high temperatures in nonaqueous enzymology, and in the fabrication of biosensor probes. In the future, development of techniques for the immobilization of multi-enzymes along with cofactor regeneration and retention system can be gainfully exploited in developing biochemical processes involving complex chemical conversions [26].

According to Ribeiro et al. [40] the use of free lipase for biodiesel production results in technical limitations, and it is practically unreliable, due to impossibility of their recovery and reuse, which in turn increases the production costs of the process, besides promoting the product contamination with residual enzyme. These difficulties can be overcome by the use of these enzymes in its immobilized form, allowing the reuse of biocatalyst several times, reducing costs, and further improving the quality of the product $[40,41]$.

Alzohairy and Khan [27] claimed that, recent advances in the design of immobilization supporting materials with tailorable pore size and surface functionality has enabled more precise control of immobilization of enzymes. New simulations of the surface characteristics of the target enzymes can be used to aid in the design of appropriate support materials. As the structure and mechanism of action of enzymes becomes available more controlled immobilization methods will be generated. The same authors concluded that, the development of cheaper and disposable array biosensors, bioreactors and biochips for the simultaneous detection of clinically important metabolites and rapid screening of diseases has attracted much attention during the recent past. The use of more and more immobilized enzymes in clinical, biotechnological, pharmacological and other industrial fields has great promise among future technologies.

\section{Enzymes for Second Generation Bioethanol}

The demand for ethanol has the most significant market where ethanol is either used as a chemical feedstock or as an octane enhancer or petrol additive. Brazil produces ethanol from the fermentation of cane juice whereas in the USA corn is used. The production of ethanol from sugars or starch impacts negatively on the economics of the process, thus making ethanol more expensive compared with fossil fuels. Hence the technology development focus for the production of ethanol has shifted towards the utilisation of residual lignocellulosic materials to lower production costs [38].

Enzymatic conversion of structural polysaccharides in plant biomass is a key issue in the development of second generation (lignocellulosic) bioethanol. The efficiency of this process depends in part on the ability of enzymes to disrupt crystalline polysaccharides, thus gaining access to single polymer chains [39]. The enzymatic alternative, using cellulase and hemicellulase, avoids the use of strong acids and results in a cleaner stream of sugars for fermentation and fewer by-products [35]

Lignocellulolytic enzymes-producing fungi are widespread, and include species from the ascomycetes (e.g. T. reesei), basidiomycetes including white-rot fungi (e.g. P. chrysosporium), brown-rot fungi (e.g. 
Fomitopsis palustris) and finally a few anaerobic species (e.g. Orpinomyces sp.) which degrade cellulose in gastrointestinal tracts of ruminant animals [42-44] Biomass degradation by these fungi is performed by complex mixtures of cellulases [44, 45], hemicellulases [43] and ligninases $[45,46]$, reflecting the complexity of the materials.

Nagendran et al. [47] cited that, a multitude of enzymatic activities are required for the conversion of lignocellulosic biomass into useful (fermentable) products. Known essential activities to degrade crystalline cellulose include cellobiohydrolase $(\mathrm{CBH})$, endo- $\beta 1,4$-glucanase (EG), and $\beta$-glucosidase (BG). A larger suite of enzymes is necessary to depolymerize hemicelluloses, including endo- $\beta 1,4$-xylanase (EX), $\beta$-xylosidase (BX), $\alpha$-arabinosidase, $\alpha$-glucuronidase, and esterase. Currently available commercial enzyme preparations for the depolymerization of lignocellulosic materials are partially defined complex mixtures of the secreted proteins from filamentous fungi such as Trichoderma Aureobasidium pullulans was presented that have been grown in the presence of inducers such as sophorose or lactose. Commercial enzyme "cellulase" mixtures contain between 80 and 200 protein. Except for a few of the better-characterized cellulases and hemicellulases, the roles of most of these proteins in lignocellulose deconstruction are poorly understood [48]. Table 3 presents an overview of the groups of fungal cellulolytic enzymes and their main features [59].

Banerjee et al. $[48,50]$ noted that, the way forward for the development of more efficient lignocellulose-degrading enzyme cocktails will require deeper and more precise knowledge about the specific enzymes that are involved in the degradation of lignocellulose. However, it is not possible to gain this knowledge working only with partially defined complex mixtures. The same authors affirmed that, the precise contribution of an individual enzyme can be established only by working with it in a purified state in a realistic enzyme cocktail.
Dashtban et al. [44] highlighted that lignocellulolytic microorganisms, especially fungi, have attracted a great deal of interest as biomass degraders for large-scale applications due to their ability to produce large amounts of extracellular lignocellulolytic enzymes. Many successful attempts have been made to improve fungal lignocellulolytic activity including recombinant and non-recombinant techniques. Process integration has also been considered for the purpose of decreasing the production cost, which was partly achieved by performing hydrolysis and fermentation in a single reactor (SSF).

On the other hand, scaling up the production of lignocellulosic ethanol, however, requires further reduction of the production cost. Overall, in order to improve the technology and reduce the production cost, two major issues have to be addressed: i) improving technologies to overcome the recalcitrance of cellulosic biomass conversion (pretreatment, hydrolysis and fermentation) and ii) sustainable production of biomass in very large amounts [42].

\section{Enzymes Global Market}

A recent report on industrial enzymes [51] revealed that, the global market for industrial enzymes was fairly immune to the recent turmoil in the global economy and grew moderately during 2008-2009. Demand for industrial enzymes in matured economies such as the US, Western Europe, Japan and Canada was relatively stable during the recent times, while developing economies of Asia-Pacific, Eastern Europe and Africa and Middle East regions emerged as the fastest growing markets for industrial enzymes. Increased demand for various specialty enzymes, polymerases and nucleases coupled with the robust growth in animal feed markets are likely to steer growth in industrial enzymes market. United States and Europe collectively command a major share of the world industrial enzymes market. On the other hand, Asia Pacific

\begin{tabular}{|c|c|c|c|c|}
\hline Lignocellulosic Fraction & Enzymes & Location of action & Mode of action & E.C number \\
\hline \multirow[t]{3}{*}{ Cellulose } & $\begin{array}{l}\text { Endo-1,4- } \beta \text {-glucanases } \\
\text { (EG) }\end{array}$ & Cellulose (amorphous regions) & $\begin{array}{l}\text { Attack the amorphous regions of the cellulose } \\
\text { and produce glucose. }\end{array}$ & 3.2.1.4 \\
\hline & $\begin{array}{l}\text { Cellobiohydrolases } \\
(\mathrm{CBH}) \\
\text { (Exo-I,4-p-glucanase) }\end{array}$ & Cellulose (crystalline regions) & 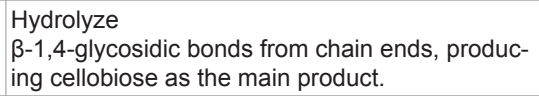 & 3.2.1.91 \\
\hline & $\beta$-glucosidases (BGL) & Cellobiose, cellodextrins & $\begin{array}{l}\text { Hydrolyze soluble } \\
\text { cellobiose and cellodextrins to glucose. }\end{array}$ & 3.2.1.21 \\
\hline \multirow[t]{7}{*}{ Hemicellulose } & Endo-xylanase & Xylan main chain & $\begin{array}{l}\text { Hydrolyzes mainly interior } \beta-1,4-x y l o s e \\
\text { linkages of the xylan backbone. }\end{array}$ & 3.2.1.8 \\
\hline & Exo-xylanase & Xylan main chain & $\begin{array}{l}\text { Hydrolyzes the terminal } \beta-1,4 \text {-xylose linkages } \\
\text { releasing xylobiose. }\end{array}$ & 3.2.1.37 \\
\hline & $\beta$-Xylosidase & Xylooligosaccharides & $\begin{array}{l}\text { Releases xylose from xylobiose and short chain } \\
\text { xylooligo-saccharides. }\end{array}$ & 3.2.1.32 \\
\hline & a-Arabinofuranosidase ${ }^{*}$ & $\begin{array}{l}\alpha-L \text {-arabinofuranosyl compounds attached } \\
\text { to the xylan main chain }\end{array}$ & $\begin{array}{l}\text { Hydrolyzes terminal nonreducing } \\
\alpha \text {-arabinofuranose from arabinoxylans. }\end{array}$ & 3.2.1.55 \\
\hline & a-Glucuronidase* & $\begin{array}{l}\alpha-1,2-\text { linked glucuronic or } 4-0- \\
\text { methylglucuronic acid substituents attached } \\
\text { to xylan main chain }\end{array}$ & Releases glucuronic acid from glucuronoxylans. & 3.2.1.31 \\
\hline & Acetylxylan esterase* & $\begin{array}{l}\text { O-Acetil groups attached to the side ends of } \\
\text { xylan main chain }\end{array}$ & $\begin{array}{l}\text { Hydrolyzes acetylester bonds in acetyl xylans, } \\
\text { liberating acetic acid. }\end{array}$ & 3.1.1.6 \\
\hline & Ferulic acid esterase* $^{*}$ & $\begin{array}{l}\text { feruloyl group on the arabinofuranosyl side } \\
\text { chain attached to the terminal non-reducing } \\
\text { xylose }\end{array}$ & $\begin{array}{l}\text { Hydrolyze the ester linkages between arabinose } \\
\text { side chain residues and phenolic acids (ferulic } \\
\text { acid). }\end{array}$ & 3.1.1.1 \\
\hline \multirow[t]{2}{*}{ Lignin } & Laccase (phenol oxidase) & $\begin{array}{l}\text { Phenolic compounds found in the lignin } \\
\text { structure }\end{array}$ & Oxidizes phenolic subunits of lignin. & 1.10.3.2 \\
\hline & $\begin{array}{l}\text { Lignin peroxidase } \\
\text { Manganese peroxidase }\end{array}$ & $\begin{array}{l}\text { Aromatic compounds found in the lignin } \\
\text { structure } \\
\text { Phenolic compounds found in the lignin } \\
\text { structure }\end{array}$ & $\begin{array}{l}\text { Oxidation of benzilic alcohols, cleavage of } \\
\mathrm{C}-\mathrm{C} \text { bonds, cleavage of } \mathrm{C}-\mathrm{O} \text { bonds. } \\
\text { Oxidation of } \mathrm{Mn}^{2+} \text { to } \mathrm{Mn}^{3+} \text {, which then binds to } \\
\text { an appropriate ligand, diffuses from the enzyme, } \\
\text { and, in turn oxidizes phenolic substrates. }\end{array}$ & $\begin{array}{l}1.11 .1 .7 \\
1.11 .1 .13\end{array}$ \\
\hline
\end{tabular}

*Known as accessory enzymes.

Table 3: Enzymes involved in lignocellulose degradation and their mode of action [50]. 


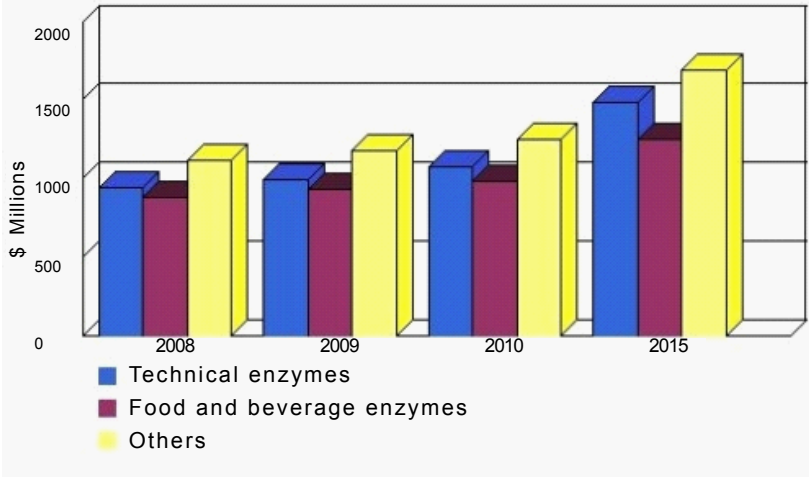

Figure 4: Global industrial enzymes market, 2008-2015.

is poised to register the fastest compounded annual growth rate of more than $8.0 \%$ over the analysis period.

Enzymes are a very well established product in biotechnology [51,52], where sales from US have been from $\$ 1.3$ billion in 2002 to US $\$ 5.1$ billion in 2009 and is anticipated to reach $\$ 7$ billion by 2013 [52-55]. A recent survey on world sales of enzymes ascribes $31 \%$ for food enzymes, $6 \%$ for feed enzymes and the remaining for technical enzymes $[53,56]$.

Regarding the global market for the industrial enzymes, a recent report published by BBC Research [57] states that the global market for industrial enzymes was estimated to reach a value of $\$ 3.3$ billion in 2010. This market is expected to reach $\$ 4.4$ billion by 2015 , a compound annual growth rate (CAGR) of $6 \%$ over the 5 -year forecast period.

Technical enzymes are valued at just over $\$ 1$ billion in 2010. This sector will increase at a $6.6 \%$ compound annual growth rate (CAGR) to reach $\$ 1.5$ billion in 2015. The highest sales of technical enzymes occurred in the leather market, followed by the bioethanol market (Figure 4). On the other hand, the food and beverage enzymes segment is expected to reach about $\$ 1.3$ billion by 2015 , from a value of $\$ 975$ million in 2010, rising at a compound annual growth rate (CAGR) of $5.1 \%$. Within the food and beverage enzymes segment, the milk and dairy market had the highest sales, with \$401.8 million in 2009 .

Major enzyme producers are located in Europe, USA and Japan. Denmark is dominating, with major players like Novozymes (45\%), Danisco (17\%), Genencor (USA), DSM (The Netherlands) and BASF (Germany) [53,58,59]. The pace of development in emerging markets suggested that companies from India and China can join this restricted party in a very near future [53,60-64].

Another recently published research report on enzymes market [51] highlighted the fact that Proteases constitutes the largest product segment in the global industrial enzymes market, and Carbohydrases market is projected to be the fastest growing product segment, with a CAGR of more than $7.0 \%$ over the analysis period. Lipases represent the other major product segment in the global industrial enzymes market with high growth potential.

The same report emphasized that, in terms of end-use, food and feed represents the largest segment for industrial enzymes. Developing regions are expected to emerge as the fastest growing consumers of industrial enzymes for food and feed applications, as increase in per capita income in these regions would continue to drive the demand for meat. Detergents constitute the other major end-use segment for indus- trial enzymes. Demand for detergent enzymes, however, is likely to be affected by the fluctuating prices of raw materials and the continuous innovations by the manufacturers to cut down on the costs. Nevertheless, a large percentage of mid-tier and low tier-detergent manufacturers are increasing the usage of enzymes in their products for offering enhanced performance.

Sectors such as pharmaceuticals and bioethanol have succeeded in drawing significant attention of the investors and are self-sufficient in undertaking new product development activities and in launching novel and unique products in the market, thus offering new opportunities to the industrial enzyme manufacturers. However, segments such as wastewater treatment chemicals and paper and pulp lack sufficient funding for carrying out new product developments [51].

According to Pitman [65], a recent report on the use of enzymes in cosmetic industry appointed that this segment is estimated to grow by $5 \%$ CAGR every year up to 2015 . Market researchers highlights the fact that industrial demands for enzymes is being driven by new enzyme technologies and increase use of organic compounds in place of petrochemical-based ingredients.

\section{Final Remarks}

Development of novel and superior performing products and rapid advances in the technology would enable industrial enzyme manufacturers to cash on the vast untapped potential in the market. Sectors such as pharmaceuticals and bioethanol have succeeded in drawing significant attention of the investors and are self-sufficient in undertaking new product development activities and in launching novel and unique products in the market, thus offering new opportunities to the industrial enzyme manufacturers. However, segments such as wastewater treatment chemicals and paper and pulp lack sufficient funding for carrying out new product developments. This is hampering the prospects of industrial enzymes companies to a large extent. In order to enhance their prospects in other segments also, industrial enzyme manufacturers are increasingly using the pharmaceutical and bio ethanol enzyme developing technologies for developing other application-specific enzymes [51].

\section{Acknowledgment} port.

The authors would like to thank FAPEMIG and CNPq for their financial sup-

\section{References}

1. Dalby PA (2003) Optimizing enzyme function by directed evolution. Curr Opin Struct Biol 13: 500-505.

2. Otten LG, Quax WJ (2005) Directed evolution: selecting today's biocatalysts Biomolecular Engineering 22: 1-9.

3. Schoemaker HE, Mink D, Wubbolts MG (2003) Dispelling the myths-biocatalysis in industrial synthesis. Science 299: 1694-1697.

4. Marrs B, Delagrave S, Murphy D (1999) Novel approaches for discovering industrial enzymes. Curr Opin Microbiol 2: 241-245.

5. Arnold FH (1998) Design by directed evolution. Acc Chem Res 31: 125-131

6. Haki GD, Rakshit SK (2003) developments in industrially important thermostable enzymes: a review. Bioresour Technol 89: 17-34.

7. Enzyme Nomenclature. Nomenclature Committee of the International Union of Biochemistry and Molecular Biology (NC-IUBMB).

8. Enzymatic Deiking Technologies EDT.

9. Lorenz P, Eck J (2005) Metagenomics and industrial applications. Nat Rev Microbiol 3: 510-516. 
Citation: Sarrouh B, Santos TM, Miyoshi A, Dias R, Azevedo V (2012) Up-To-Date Insight on Industrial Enzymes Applications and Global Market. $J$ Bioprocess Biotechniq S4:002 doi:10.4172/2155-9821.S4-002

10. Falch EA (1991) Industrial Enzymes - Developments in Production and application. Biotech Adv 9: 643-658.

11. Leisola M, Jokela J, Pastinen O, Turunen O, Schoemaker H (2002) Industria use of enzymes. In: Encyclopedia of Life Support Systems (EOLSS), EOLSS.

12. Aravindan R, Anbumathi P, Viruthagiri T (2007) Lipase applications in food industry. Indian Journal of Biotechnology 6: 141-158.

13. Brijwani K, Rigdon A, Vadlani PV (2010) Fungal Laccases: Production, Function, and Applications in Food Processing. Enzyme Research 2010: 1-10.

14. Industrial Enzymes.

15. Chaplin MF, Bucke C (1990) Enzyme Technology. (1 ${ }^{\text {st }}$ edn) Cambridge University Press, Cambridge, England

16. K. Vaňková, Antošová M, Polakovič M (2005) Design and Economics of Industrial Production of Fructosyltransferase. Chem Pap 59: 441- 448.

17. Enzyme Technology.

18. van Beilen JB, Li Z (2002) Enzyme technology: an overview. Curr Opin Biotechnol 13: 338-344.

19. Market Research News (2011) In: Report - Global Industrial Enzymes Market: An Analysis

20. Enzyme Technical Association (2001) Enzymes a primer on use and benefits today and tomorrow - Report. Washington, DC.

21. Cowan D (1996) Industrial enzyme technology. Trends Biotechnol 14: 177-178.

22. Kirk O, Borchert TV, Fuglsang CC (2002) Industrial enzyme applications. Curr Opin Biotechnol 13: 345-351.

23. Howard RL, Abotsi E, van Rensburg JEL, Howard S (2003) Review- Lignocellulose biotechnology: issues of bioconversion and enzyme production. Afr $J$ Biotechnol 2: 602-619.

24. Eijsink VGH, Vaaje-Kolstad G, Vårum KM, Horn SJ (2008) Towards new enzymes for biofuels: lessons from chitinase research. Trends Biotechnol 26 228-235

25. Enzymes, Therapeutic Proteins and Recombinant products.

26. D'Souza SF (1999) Immobilized enzymes in bioprocess. Curr Sci 77: 69-79.

27. Alzohairy MA, Khan AA (2010) Recent Advances and Applications of Immobilized Enzyme Technologies: A Review. Res J Biolog Sci 5: 565-575.

28. Mahmoud DAR, Helmy WA (2009) Potential Application of Immobilization Technology in Enzyme and Biomass Production. J Appl Sci Res 5: 2466-2476.

29. Hartmier W (1988) Immobilized Biocatalysts: An Introduction (1 ${ }^{\text {st }}$ edn), Springer-Verlag publisher, Berlin, Germany.

30. Gekas V, Lopeiz-Leiva M (1985) Hydrolysis of lactose: a literature review. Process Biochem 20: 2-12.

31. Rao BYK, Godbole SS, D'Souza SF (1988) Preparation of lactose free milk by fermentation using immobilized Saccharomyces fragilis. Biotechnol Lett 10: 427-430. http://www.springerlink.com/content/wq5073684u811604/

32. Tampion J, Tampion MD (1987) Immobilized Cells: Principles and Applications, Cambridge University Press, Cambridge, England.

33. D'Souza SF (1989) Immobilized cells: Techniques and applications. Indian $J$ Microbiol 29: 83-117.

34. Ramakrishna SV, Prakasham RS (1999) Microbial fermentations with immobilized cells. Curr sci 77: 87-101.

35. Báleš V (1994) Bioprocesses with immobilized biocatalyst-engineering aspects. App Biochem Biotechnol 48: 5-10.

36. Fei G, Ma GH, Wang P, Su ZG (2010) Enzyme Immobilization, Biocatalyst Featured with Nanoscale Structure. Encyclopedia of Industrial Biotechnology: Bioprocess, Bioseparation, and Cell Technology 1-26.

37. Dalal S, Sharma A, Gupta MN (2007) A multipurpose immobilized biocatalys with pectinase, xylanase and cellulase activities. Chemistry Central Journal 1: $1-5$.

38. Fernandes P, Marques MPC, Carvalho F, Cabral JMS (2009) A simple method for biocatalyst immobilization using PVA-based hydrogel particles. JCTB 84: 561-564.
39. Mattiasson Bo (1983) Immobilized cells and organelles. CRC Press, Boca Raton, Florida, USA.

40. Ribeiro BD, Castro AM, Coelho MAZ, Freire DMG (2011) Production and Use of Lipases in Bioenergy: A Review from the Feedstocks to Biodiesel Production. Enzyme Research 2011:1-16

41. Tan T, Lu J, Nie K, Deng L, Wang F (2010) Biodiesel production with immobilized lipase: a review. Biotechnol Adv 28: 628-634.

42. Ljungdahl LG (2008) The cellulase/hemicellulase system of the anaerobic fungus Orpinomyces PC-2 and aspects of its applied use. Ann NY Acad Sci 1125: 308-321.

43. Yoon JJ, Cha CJ, Kim YS, Son DW, Kim YK (2007) The brown-rot basidiomycete Fomitopsis palustris has the endo-glucanases capable of degrading microcrystalline cellulose. J Microbiol Biotechnol 17: 800-805.

44. Dashtban M, Schraft H, Qin W (2009) Fungal Bioconversion of Lignocellulosic Residues; Opportunities \& Perspectives. Int J Biol Sci 5: 578-595.

45. Weng JK, Li X, Bonawitz ND, Chapple C (2008) Emerging strategies of lignin engineering and degradation for cellulosic biofuel production. Curr Opin Biotechnol 19: 166-172.

46. Sanchez C (2009) Lignocellulosic residues: biodegradation and bioconversion by fungi. Biotechnol Adv 27: 185-194.

47. Nagendran S, Hallen-Adams HE, Paper JM, Aslam N, Walton JD (2009) Reduced genomic potential for secreted plant cell-wall-degrading enzymes in the ectomycorrhizal fungus Amanita bisporigera, based on the secretome of Trichoderma reesei. Fungal genet Biol 46: 427-435.

48. Banerjee G, Scott-Craig JS, Walton JD (2010) Improving Enzymes for Biomas Conversion: A Basic Research Perspective. Bioenerg Res 3: 82-92.

49. Saha BC (2004) Lignocellulose biodegradation and applications in biotechnology. American Chemical Society 889: 2-34.

50. Banerjee G, Car S, Scott-Craig JS, Borrusch MS, Aslam N, et al. (2010) Synthetic Enzyme Mixtures for Biomass Deconstruction: Production and Optimization of a Core Set. Biotechnol Bioeng 106: 707-720.

51. Global Industry Analysts, Inc (2011) In: Report - Global Strategic Business.

52. Norus J (2006) Building sustainable competitive advantage from knowledge in the region: the industrial enzymes industry. European Planning Studies 14 681-696.

53. Agrahari S (2011) Production of Enzymes and Degradation of Feathers by Soil Microbes. Jaypee Institue of Information Technology 1-12.

54. Schafer T, Kirk O, Borchert TV, Fuglsang C, Pedersen S, et al. (2005) Enzymes for technical applications. Biopolymers 7: 377-387.

55. El Enshasy H, Abuoul-Enein A, Helmy S, El Azaly Y (2008) Optimization of the industrial production of alkaline protease by Bacillus licheniformis in different production scales. Aus J Appl Sci 2: 583-593.

56. Berka RM, Cherry JR (2006) Enzyme biotechnology, in: Basic Biotechnology. (3rdedn) Cambridge University Press, Cambridge, UK.

57. BBC Research (2011) In Report BIO030F - Enzymes in Industrial Applications: Global Markets.

58. Binod P, Singhania RR, Soccol CR, Pandey A (2008) Industrial enzymes, in Advances in Fermentation Technology. Asiatech Publishers, New Delhi, India.

59. BCC-Business Communications Company, Inc., (2009) In: Report FOD020C World markets for fermentation ingredients, Wellesley, MA 02481.

60. Ogawa J, Shimizu S (2002) Industrial microbial enzymes: their discovery by screening and use in large-scale production of useful chemicals in Japan. Cur Opin Biotechnol 13: 367-375.

61. Chandel AK, Rudravaram R, Rao LV, Ravindra P, Narasu ML (2007) Industria enzymes in bioindustrial sector development: an Indian perspective. Journal of Commercial Biotechnology 13: 283-291.

62. Carrez D, Soetaert W (2005) Looking ahead in Europe: white biotech by 2025 Ind Biotechnol 1: 95-101.

63. Research and Markets (2011) In: Report - Chinese Markets for Enzymes. 
Citation: Sarrouh B, Santos TM, Miyoshi A, Dias R, Azevedo V (2012) Up-To-Date Insight on Industrial Enzymes Applications and Global Market. J Bioprocess Biotechniq S4:002 doi:10.4172/2155-9821.S4-002

Page 10 of 10

64. Research and Markets (2011) In: Report - Indian Industrial Enzymes Market.

65. Pitman S (2011) Growth in enzyme market driven by cosmetic demand. Online news, Cosmetics design.
66. Freedonia Group Inc (2009) In: Report 2506 - World Enzymes-Industry Study with Forecasts for 2013 \& 2018.

67. Bayer EA, Chanzy H, Lamed R, Shoham Y (1998) Cellulose, cellulases and cellulosomes. Curr Opin Struct Biol 8: 548-557. 